\title{
HISTOLOGICAL AND ULTRA STRUCTURAL STUDY OF THE EFFECT OF MONOSODIUM GLUTAMATE ON THE SUBMANDIBULAR SALIVARY GLAND OF ADULT ALBINO RATS
}

\author{
Heba Fathy El Imam* and Nesreen Nabil abd El Salam **
}

\begin{abstract}
Introduction: Monosodium glutamate (MSG) is used as a food flavor enhancer all over the world. However, it has adverse effects on human and experimental animals at different organs. Aim: This is study designed to evaluate the histological and the ultrastructure effect of two different doses of MSG on submandibular salivary gland (SMG) of albino rats.
\end{abstract}

Materials and Methods: Fifteen adult male albino rats (180 -200 gm). They were randomly divided into three groups $(\mathrm{n}=5)$. The control group I: rats were received $1 \mathrm{ml}$ distilled water orally once daily for 8 weeks. The experimental groups, group II, group III: rats were received $15 \mathrm{mg} /$ $\mathrm{kg}$ and $30 \mathrm{mg} / \mathrm{kg} \mathrm{b}$. wt. respectively of MSG dissolved in $0.2 \mathrm{ml}$ of distilled water orally once daily for 8 weeks. Animals were sacrificed and two pairs of (SMG) were dissected out, left side was processed for light microscopic examination LM and the right one for transmission electron microscopic examination TEM.

Results: LM examination of group II revealed some serous acini lost their normal arrangement. The acini were distended, their cytoplasm was vacuolated and some of them were degenerated. Nuclear changes appeared in form of large, hyperchromatic, pleomorphic and some pyknotic nuclei. Dilated intercalated and striated ducts with ill-defined cell borders. Enlarged blood vessels that engorged with red blood cells RBCs found between the acini and the striated ducts. Mucous acini has irregular arrangement with vacuolated cytoplasm and nuclear changes. Group III revealed loss of normal glandular architecture, abnormal shape of serous and mucous acini, obvious nuclear changes. The ductal cells were dilated and blood vessels engorged with RBCs with inflammatory cell infiltration in connective tissue. TEM examination of group II revealed mild changes as irregular outline of electron dense nucleus, occasional confluence of secretory granules. Marked dilatation of ruff endoplasmic reticulum, few number of lysosomes and mild dilatation of intracellular canaliculi. These changes were more obvious at group III.

Conclusion: From the present study we concluded that MSG has degenerative changes at acini and ductal cells of (SMG). Therefore, we recommended that excessive consumption of food containing this salt should be avoided.

KEY WORDS: Monosodium glutamate, submandibular

* Lecturer of Oral Biology, Faculty of Dentistry, Egyptian Russian University, Cairo, Egypt.

** Lecturer of Oral Biology, Faculty of Dentistry, Mansoura University, Mansoura, Egypt. 


\section{INTRODUCTION}

Food additives that applied to the basic food stuffs can produce a special color or taste where it acts either as preservatives, or to alter the taste. One of them is Monosodium glutamate (MSG) which is present at sold form in most open market stalls and stores in Nigeria as "Ajinomoto" marketed by West African Seasoning Company Limited (1). It is the sodium salt of glutamic acid (GA) containing $78 \%$ of glutamic acid, $22 \%$ of sodium and water and has many market names such as Ajinomoto, Chinese salt, and E621 (2). According to the United State Food and Drug Administration (FDA), MSG is classified as generally safe with no specified limit daily intake requirement and described by the European Union as a food additive (E621), describing it as a "Flavouring" or "Hydrolysed vegetable protein" (3).

MSG is found in a wide variety of packaged foods such as chocolate milk, cocoa, energy drink, milk powder, cream powder, dried, canned vegetables (including mushrooms), nuts, custard and chips (4). Moreover, glutamate occurs naturally in various foods including poultry, cheeses, meat broths, seafood and vegetables (5). Also, MSG entered in many processed foods such as prepared meats, tuna, marinated meats, canned soups or sauces, vegetarian burgers, luncheon chicken, turkey and sausages ${ }^{(6)}$. It can produce a unique taste, known as umami taste that improve the quality of food intake by stimulating the chemosensory perception. So, this taste enhancer is widely used in the food industry, in restaurants and homes ${ }^{(7)}$.

Many studies reported that MSG has adverse effects on human and experimental animals at different organs. Higher doses of MSG were investigated to be neurotoxic in experimental animals; as it destructs neurons in the hypothalamic nuclei through their changes in the hypothalamopituitary-adrenal axis ${ }^{(8)}$, damage of liver, testes and kidney (9). These findings could be explained that unbound glutamate dissociated from MSG may act on certain receptors in the central or peripheral neurons, causing histopathological changes ${ }^{\left({ }^{(10)}\right.}$. Also, intake of MSG has been associated with increased risk of overweight independent of physical activity and total energy intake (11).

Salivary glands secrete saliva which plays a vital role in maintaining general health of the oral tissues. It has a role in lubrication, digestion, enamel preservation, antibacterial, antifungal and anti-inflammatory effect. It acts as a first barrier against infections as it contains proteins and peptides. So that, the reduction in salivary flow may lead to the oral mucosal inflammation, increased incidence of dental caries, dry mouth, chewing and swallowing disorders, loss of the sense of taste. The submandibular salivary gland is the second largest salivary gland, it produces about $60 \%$ of saliva ${ }^{(12)}$.

Oxidative stress is caused by excessive production of free radicals which acting on unsaturated fatty acids and proteins of cell membranes resulting in production of lipid peroxidase and protein carbonyl causing destruction of organelles and macromolecules. Whereas, these oxidative-stressinduced damage to DNA and macromolecules resulting in development of many diseases including cardiovascular disease, neurological degenerations (e.g., Alzheimer's disease, ischemic stroke), cancer and the normal ageing processes ${ }^{(13) .}$ Thus, chronic intake of MSG causing oxidative damage and decreased levels of antioxidant enzymes resulting in impairment in kidney, liver and brain functions ${ }^{(14) .}$ It has been reported that long term administration of MSG to male albino rats revealed neoplastic changes in parotid salivary gland in form of loss of glandular architecture ${ }^{(15)}$.

In this regard, literatures investigating the effect of MSG on the morphology and function of salivary glands are few and controversial. So, the aim of our study is to evaluate the histological and the ultrastructure effect of two different doses of MSG on submandibular salivary gland of rats. 


\section{MATERIAL AND METHODS}

\section{Animals:}

Fifteen adult male albino rats weighing between 180 -200 gm were obtained from animal house, Mansoura University, faculty of medicine. The rats were maintained adequate diet throughout the experimental period and kept in separate stainless steel cages under controlled conditions at constant temperature $\left(24^{\circ} \mathrm{C}\right)$, good ventilation.

\section{Materials:}

Monosodium glutamate (C5H9NO4.-Na) Purity 99\% NT. it is sold in most super markets in Egypt under the license of Ajinomoto co. INC. Tokyo, Japan.

\section{Experimental Design:}

Animals were adapted for one week. After that, they were randomly divided into three groups with five rats each.

The groups were classified into:

- Group I: rats were kept under normal condition and were received $1 \mathrm{ml}$ distilled water orally once daily for 8 weeks and considered as control group.

- Group II: rats were received $15 \mathrm{mg} / \mathrm{kg}$ body weight of MSG dissolved in $0.2 \mathrm{ml}$ of distilled water orally once daily for 8 weeks.

- Group III: rats were received $30 \mathrm{mg} / \mathrm{kg}$ body weight of MSG dissolved in $0.2 \mathrm{ml}$ of distilled water orally once daily for 8 weeks ${ }^{(16) .}$

At the end of the experiment, animals were sacrificed under anesthesia. The two pairs of submandibular salivary gland (SMG) were dissected out and left one processed for light microscopic examination LM and the right one was processed for transmission electron microscopic examination TEM.

\section{Specimen's collection and preperation:}

After dissection of (SMG) of all groups. The left side was immediately fixed in $10 \%$ in buffered formalin for $24 \mathrm{~h}$ and embedded in paraffin. $5-\mu \mathrm{m}$ thick were taken from paraffin-embedded tissues and mounted on clean glass slides and stained by H\&E ${ }^{(17) .}$ Then, examined under a light microscope.

While, the right side of all groups were cut into small parts of one cubic mm. Then were fixed in glutraldehyde to be prepared for ultra structural examination by the transmission electron microscope (TEM). Specimens were washed at three changes of phosphate buffer at $\mathrm{pH}$ 7.4. Secondary fixation was done in $1 \%$ osmium tetraoxide at $40 \mathrm{C}$, for 1.5 hours followed by rinsing in phosphate buffer. Then, they were dehydrated in ascending grades of ethyl alcohol, cleared in propylene oxide and embedded in epoxy resin. Semi thin sections of 1-2 microns were cut and stained with $1 \%$ toluidine blue and examined by light microscopy (LM) for detection of the site to be examined by trans-mission-electron microscopes (TEM) ${ }^{(18) .}$ Then, ultrathin sections were cut using ultra-microtome, mounted on copper grids and stained with uranyl acetate and lead citrate. The grids were examined by Joel TEM $100 \mathrm{CX}$ at magnification of 4000x at (TEM) unit, Mycological center, Al-azhar University.

\section{RESULTS}

\section{Light microscope results}

\section{Group I:}

Examination of (SMG) of this group showed normal architecture of acinar and ductal cells with the secretory terminal portions predominantly of the serous cells that composed of pyramidal cells with basophilic cytoplasm which surrounding a narrow lumen and mucous cells composed of flattened cells with wide lumen and clear cytoplasm. The duct system has intercalated and striated ducts. Also, it showed granular convoluted tubules that 
is characterized by their columnar cells containing excretory granules. Whereas, striated ducts having a wider lumen compared to intercalated ducts and low columnar cells with centrally placed nucleus and basal striation (Fig.1 a \& b).

\section{Group II:}

Examination of (SMG) of this group revealed that some serous acini lost their normal arrangement with ill-defined margins. Acini appeared distended and their cytoplasm was vacuolated, some of them were degenerated. Nuclear changes appeared in form of large, hyperchromatic, pleomorphic and some pykontic nuclei, also many mitotic figure were observed. Intercalated ducts were dilated with ill-defined cell borders. The striated ducts showed ill-defined borders, some pyknotic nuclei, and interruption of basal striations. Enlarged blood vessels that engorged with red blood cells (RBCs) found between the acini and adjacent to the striated ducts. Mucous acini appeared with irregular arrangement, vacuolated cytoplasm and nuclear changes, the striated duct showed ill-defined margins and enlarged blood vessels adjacent to the duct (Fig.1 c \&d).

\section{Group III:}

Examination of (SMG) of this group revealed loss of normal glandular architecture, abnormal shape of serous acini and haphazard arrangement with indistinct cell boundaries. Some acini showed vacuolated cytoplasm. Nuclear pleomorphism and hyperchromatism with increased nuclear cytoplasmic ratio were clearly appeared. Abnormal mitotic figures were also observed. Intercalated ducts, striated duct and excretory ducts became dilated. Mucous acini has loss of cell borders while striated ducts showed nuclear pleomorphism, ill-defined cell borders and distortion of basal striation. Blood vessels were markedly enlarged with extravagated RBCs and inflammatory cell infiltration in connective tissue around excretory duct. (Fig.1 e \&f).

\section{Transmission electron microscopic results}

\section{Group I:}

Examination of (SMG) at this group showed normal pyramidal cells with basal round nuclei which has dense areas of chromatin at the periphery of the nucleus and defined nuclear envelop, intact cell boundaries, normal intercellular canaliculi and accumulated secretory granules of varying size and density. Normal ductal cells (intercalated duct) with abundant mitochondria and normal nuclei and normal intercellular canaliculi. Mucous acini showed normal low pyramidal cells with basal flattened nucleus and radiolucent secretory granules (Fig.2 a, b) .

\section{Group II:}

Examination of (SMG) at this group showed mild changes represented in electron dense nucleus having an irregular outline, occasional confluence of secretory granules. Their cytoplasm revealed marked dilatation of ruff endoplasmic reticulum, few number of lysosomes, few intracytoplasmic vacuoles and mild dilatation of intracellular canaliculi. (fig. 2 c).

\section{Group III:}

Examination of (SMG) at this group showed obvious changes as wide perinuclar membrane, distended rough endoplasmic reticulum cisternae (RER), irregular nuclei with clumping and margination of heterochromatin, degenerated mitochondria, increased number of lysosomes, marked dilated intracellular canaliculi and illdefined secretory granules outlines. Intercalated duct and striated duct have ill-defined cell boundaries and dilated lumen (fig. 2 f, d,e). 

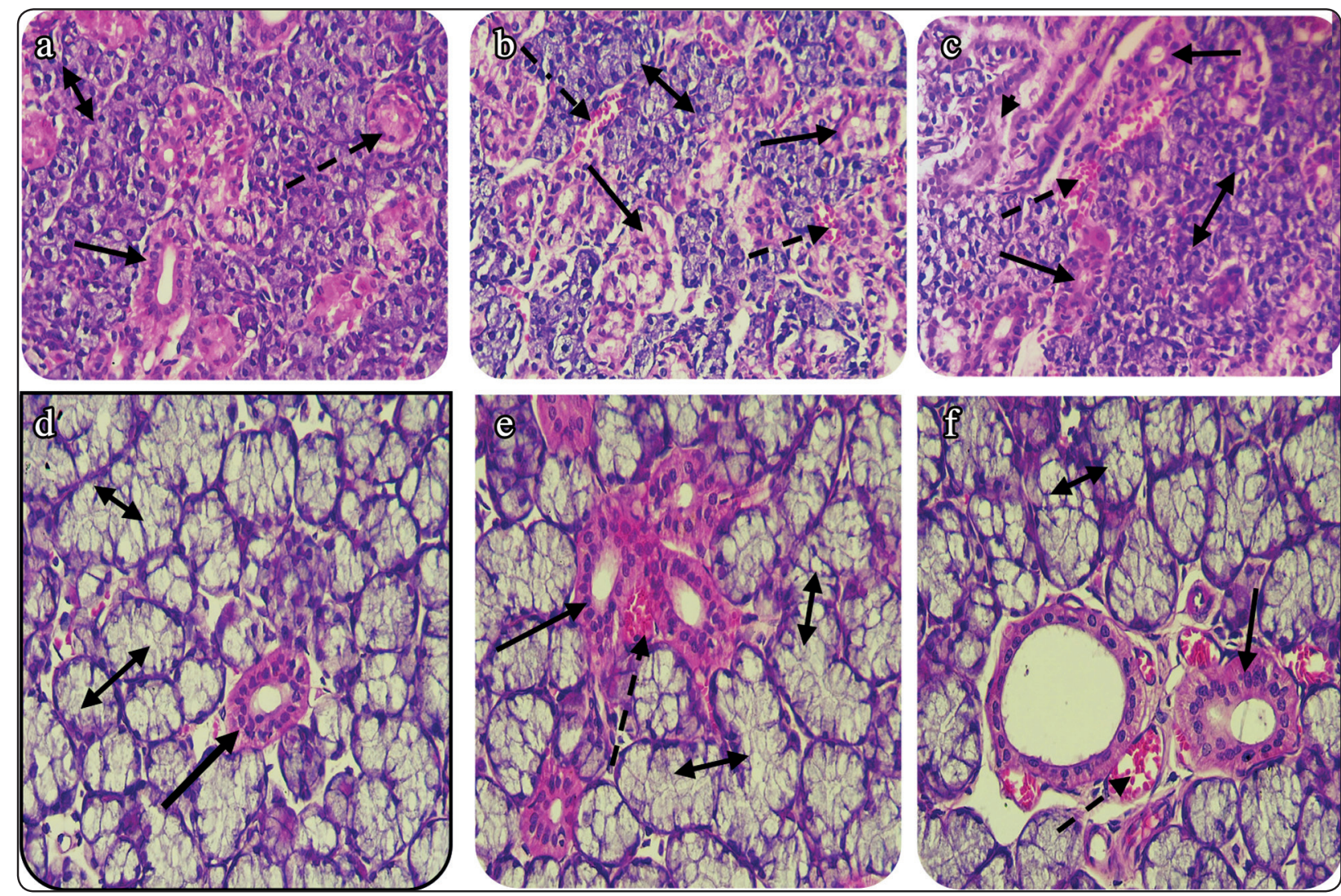

Fig. (1) A photomicrograph of (SMG) from all examined groups showing: a- Normal architecture of serous acini (double arrow) with duct system composed of intercalated ducts (dashed arrow), striated ducts (arrow) together with granular convoluted tubules at group I. b- Normal architecture of mucous acini (double arrow) with duct system composed of striated ducts (arrow) at group I. c- Lose of normal arrangement of serous acini with ill-defined margins vacuolated cytoplasm, some pyknotic nuclei (double arrow). Ill-defined borders of striated duct (arrow) and congested blood vessel (dashed arrow) at group II. d- Mucous acini has irregular arrangement (double arrow), ill-defined margins of striated duct (arrow) and enlarged blood vessels (dashed arrow) at group II. e- Abnormal shape of serous acini with indistinct boundaries and vacuolation of the cytoplasm (double arrow), dilated striated duct (arrow) and excretory ducts (arrow head), inflammatory cell infiltrated and congested blood vessel with extravagated RBCs (dashed arrow) at group III. f- Ill-defined margins of mucous acini (double arrow), striated ducts (arrow) has nuclear pleomorphism, congested blood vessel with extravagated RBCs (dashed arrow) and inflammatory cell infiltrated at group III. 

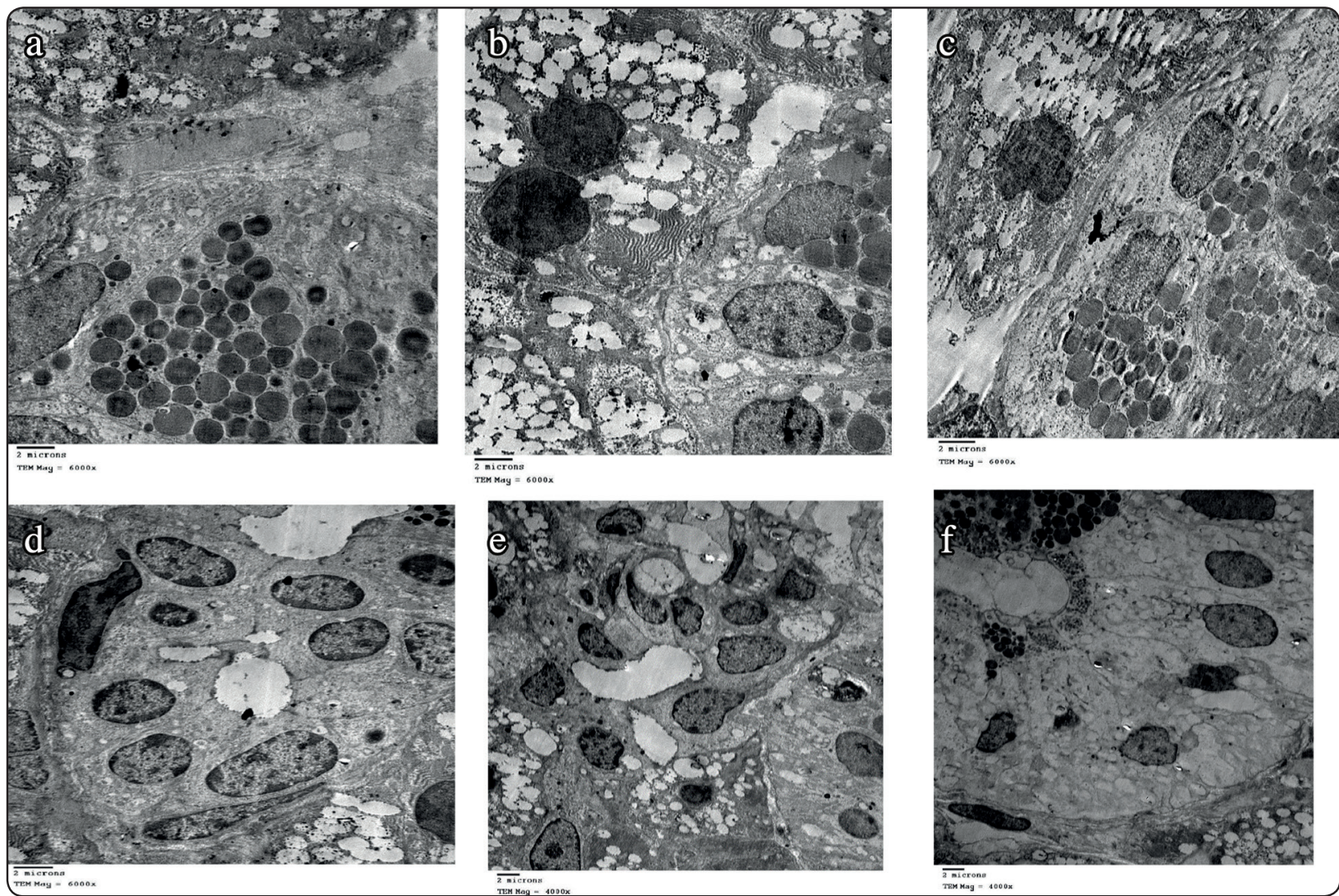

Fig. (2) TEM of SMG from all examined groups showing: a- SMG cells with intact cell boundaries, normal intercellular canaliculi and electron dense basal nucleus with well intact and defined nuclear envelop and secretory granules of varying size and density at group I. b- Intercalated duct of SMG with normal nuclei and normal intercellular canaliculi at group I. cSMG cells with electron dense nucleus having an irregular outline, cytoplasm has marked dilatation of ruff endoplasmic reticulum, few number of lysosomes, occasional confluence of secretory granules, few intracytoplasmic vacuoles and mild dilatation of intracellular canaliculi at group II. d- Intercalated duct of SMG with ill-defined cell boundaries and dilated lumen at group III. e- Striated duct with ill-defined cell boundaries together with its dilated lumen at group III. f- SMG cells with electron dense nucleus having ill-defined outline, fusion of several secretory granules, marked dilatation of rough endoplasmic reticulum, degenerated mitochondria and marked dilated intracellular canaliculi at group III. (Uranyl acetate and lead citrate Mag. $\times 6000)$

\section{DISCUSSION}

Monosodium glutamate (MSG) is the sodium salt of glutamic acid and the most applied food additives in the modern nutrition usually used as a food flavor enhancer all over the world ${ }^{(\mathbf{1 9 )},(20) .}$ On the other side, many previous studies done by Tawfik, Al-Badr, $2012{ }^{\text {(21) }}$ who reported that (MSG) has hazards and toxic effects in human and animals including allergic reaction; flushing, sweating, numbness, weakness, dizziness and headaches. It increases the appetite therefore, it is considered as a cause of weight gain ${ }^{(22)}$. It has related decline effect in the overall health of the body. It is toxic effects were occurred due to its ability to generate reactive oxygen species (ROS) and decrease the activites of the antioxidant enzymes such as superoxide dismutase activity (SOD) and glutathione metabolizing enzymes like glutathione reductase and glutathione peroxidase as stated by Soliman, $2011^{(23)}$.

However, chronic administration of MSG more than $4 \mathrm{mg} / \mathrm{g}$ body weight was found to induce oxidative stressinexperimental animals as mentioned

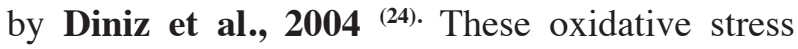
cause biochemical disequilibrium propitiated by 
excessive production of free radicals (FR) and ROS, which results in oxidative damage to biomolecules that cannot be tolerated by antioxidative systems as explained by Minibayeva, et al., $2009{ }^{(25) .}$ The salivary glands produce peroxidase enzyme that protect against toxic agents including carcinogenic and mutagenic compounds in many respects to Miletich, 2010 (26), however, glandular hypofunction can results in exposure of the gland tissue to these agents and cause morphological alteration including malignant transformation as stated by Jouzdani, et al., $2010{ }^{\text {(27). }}$ As well as MSG administration resulted in a decrease in ascorbic acid level which leads to oxidative damage in rat different organs as mentioned by Moreno, et al., $2005^{(28) .}$

The present work aimed to evaluate the histological and the ultrastructure effect of two different doses of MSG on submandibular salivary gland of adult albino rats.

In this study different doses of MSG were used for eight weeks. The selected doses were chosen according to the toxicity levels of MSG administration on different body organs as reported by Eweka, Om'Iniabohs, $2011^{(29) .}$

At the current study, light microscopical examination of group I showed granular convoluted tubules that characterized by their columnar cells containing excretory granules. This result is analogous in many respects to that of Amano, et al., $2012{ }^{(30)}$ who found this granular duct (granular convoluted tubule, GCT) which is located between the intercalated duct (ID) and striated duct (SD) in the rodent submandibular salivary gland that is lined by a simple columnar epithelium has secretory cell containing many secretory granules in its supranuclear cytoplasm. These granules contain a variety of active polypeptides such as cell growth factors and hormones that are secreted in response to neural and hormonal stimuli.

Histological results of group II, revealed some serous acini lost their normal arrangement with ill- defined margins and nuclear changes in form of large, hyperchromatic, pleomorphic and some pyknotic nuclei. Intercalated ducts and striated ducts were dilated with ill-defined cell borders. Also, Enlarged blood vessels engorged with RBCs found between the acini and adjacent to the striated ducts. However, at group III the histological results were more apparent as serous and mucous acini has abnormal shape with indistinct boundaries, more nuclear changes, the ductal cells dilated and blood vessels were markedly enlarged with extravagated RBCs and inflammatory cell infiltration in connective tissue. This findings were in agreement with Eweka, and Om'Iniabohs, $\mathbf{2 0 0 8}^{\left({ }^{(31)}\right.}$ who explained the cellular hypertrophy of hepatocyte in animal received $3 \mathrm{gm}$ and $6 \mathrm{gm}$ of MSG. and also in agreement with Eweka, et al., $2010{ }^{(32)}$ who revealed more cellular hypertrophy of fallopian tube in animals treated with $0.08 \mathrm{mg} / \mathrm{kg}$. b.wt more than animals treated with $0.04 \mathrm{mg} / \mathrm{kg}$ MSG.

Examination of group II revealed vacuolization of cytoplasm of both acini and ductal cells was in accordance with Abou-Zeid, et al., $2014{ }^{\text {(33). }}$ Also, in accordance with

EL-Kenawya, et al., $2013^{(34)}$ who demonstrated these vacuoles in hepatocyte of rats treated with 6 $\mathrm{mg} / \mathrm{g}$. b.wt MSG, and explained this cytoplasmic vacuolation due to mitochondrial damage induced by MSG. This notion is supported by Farombi, Onyema $2006{ }^{(35)}$ who stated that MSG was responsible for production of $\mathrm{O} 2$ and $\mathrm{O} 2$-free radicals, which lead to increase in lipid peroxidation and also acts as important messenger for many pathological conditions by increasing cytosolic-free calcium causing increased in the membrane permeability and swelling of cells. To maintain ATP levels, glycolysis occurred to maintain ATP levels producing lactic acid and causing decrease in the intra-cellular $\mathrm{pH}$ leading to dysfunction of sodium-potassium ATPase and consequent cell membrane damage, mitochondrial and lysosomal damage. 
Regarding the nuclear hypertrophy which most obvious findings at group II and more apparent at group III. These observations were in agreement with Leshchenko, et al., $2012{ }^{(36)}$ who found that MSG intake at the same doses used in our study significantly increases the cross-sectional area of nuclei of exocrine and endocrine cells of pancreas. Also, in agreement with Bhattacharya et al., 2011 (37) who examined the long term effect of MSG on the liver. Moreover, nuclear hypertrophy of cell with oxidative cell damaged DNA more correlated with biosynthetic activities such as DNA repair/synthesis, transcription activity and translation efficiency as mentioned by Koda, et al., $2006{ }^{{ }^{(38)} \text {. }}$

In concern with nuclear pleomorphism detected at group II and more apparent at group III, these findings were somehow relevant to AL-Mosaibih, $2013{ }^{(39)}$ who revealed that hepatocytes nuclei showed pyknosis and pleomorphism in a study carried on rat liver cells injected with $30 \mathrm{mg} / \mathrm{kg}$ body weight of MSG. Also, in in agreement with Khalaf, Arafat, $2015{ }^{(40)}$ who investigated the effects of different doses of MSG on the morphometric and histological changes of the thyroid gland and showed follicular hyperplasia in some follicles with appearance of multiple pyknotic nuclei in follicular and interfollicular cells. This is pyknosis of cell nuclei might indicate the loss of functional efficiency of the cells as suggested by Alalwani, $2013^{(41) \cdot}$

Also, our histological results showed that there were loss of normal glandular architecture which more obvious at group III. This were in consistent with Kumbhare, $2015{ }^{(42)}$ who revealed cyto-architectural alternation in liver of adult rats treated with MSG and in accordance with Dixit, $2014{ }^{(43)}$ who revealed the same finding in kidney. Moreover, the same finding was reported in thyroid of MSG treated group where some of the follicles appeared distorted, triangular, and rectangular in shape as demonstrated by Rani, $2013{ }^{(44) .}$
Meanwhile, the inflammatory cell infiltration in connective tissue observed at group III which agreed with the studies done by Kumbhare, et al., $2015^{(45)}$ who stated that the migration of leucocytes towards the area of inflammation known as chemotaxis occurred in response of body tissue to any injurious agents. Furthermore, dilated and congested blood vessels demonstrated at group II and group III were in agreement with Alalwani, $2013{ }^{(46)}$ who found dilated congested inter tubular blood vessels of testis in MSG treated animals. This congestion of blood vessels might be due to the inhibition of prostaglandin synthesis, as these compounds are known to be involved in regulation of blood flow as explained by Oladipo, $2015^{(47)}$. Also, in agreement with Eweka, $2011{ }^{(48)}$ who noted the presence of hemolysis of RBCS in central vein and hemorrhagic necrosis in centrilobular and disruption of architecture of liver as a response of oral MSG in adult rats.

Our study ultrastructural findings showed evidence of cell injury represented as dilated rough endoplasmic reticulum (RER), wide perinuclear membrane, irregular nuclei with, clumping and margination of heterochromatin, degenerated mitochondria and ill-defined secretory granules that showed at group II and more obvious at group III. These were in accordance with Lee, Sheen, $1994{ }^{(49)}$ who revealed degenerative ultrastructural changes in pancreatic acinar cells of MSG treated rats in a concentration of $1 \%$ MSG for 1 month and observed the presence of numerous large size autophagic vacuoles, dilatation of rough endoplasmic reticulum and swollen vacuolated mitochondria. A similar ultrastructure was previously described in proximal convoluted renal tubules of MSG treated rats as revealed by Afeefy, 2012 ${ }^{(\mathbf{5 0})}$. Also, in agreement with the results of Khalaf, Arafat, $2015{ }^{(40)}$ who revealed follicular cells with irregular hyperchromatic nuclei, marked dilatation of RER and increased lysosomes with areas of short or lost apical microvilli when applied doses of $3 \mathrm{~g} / \mathrm{kg}, 6 \mathrm{~g} / \mathrm{kg}$ respectively daily of MSG for one month. 
Also our electron microscopic examination revealed destruction in the cytoplasmic organelles including lysosomes, ruff endoplasmic reticulum, mitochondria and Golgi apparatus. These could be due to the cytotoxic effects of MSG. as stated by Thomas, $1988{ }^{(51)}$ who explained that Golgi apparatus is responsible for the packaging of hydrolytic enzymes which involved in the formation of secretary products. Science the destruction of Golgi apparatus leads to destruction of lysosomes which leads to an increase in secretion of hydrolytic enzymes which may be responsible for destruction of cytoplasmic organelles. This is in contrary to results of Adejoke et al., $2013^{(52)}$ who reported that despite the presence of biochemical derangements, no morphologic evidence of liver or kidney injury was observed in groups of animals fed with MSG/SD.

In consistence with our observations, Moubarak, et al., $2015^{{ }^{(53)}}$ where they evaluated the different doses of MSG on parotid gland of male rats and concluded that long term administration of MSG revealed neoplastic changes in form of loss of glandular architecture with cellular atypia and anaplasia. Also, our findings were in agreement with Shredah, Nagy, $2017^{\left({ }^{(5)}\right)}$ who investigated the two different doses of MSG on sublingual salivary gland histologically and immunohistochemically and concluded that its degenerative changes.

From this study, we concluded that when Monosodium glutamate MSG was applied in successive doses, it revealed degenerative changes at acini and ductal cells of submandibular salivary gland. Therefore, we recommended that excessive consumption of food containing this salt should be avoided.

\section{REFERENCES}

1- Moore KL: Congenital malformations due to environmental factors; Developing Humans W.B. Saunders Co. Ltd Philadelphia. 2 ${ }^{\text {nd }}$ Ed. 2003; Chap 8: 173-183.

2- Eweka AO, Om Iniabohs FAE: Histological studies of the effects of monosodium glutamate on the small intestine of adult Wister rats. Electron J. Biomed. 2007; 2:14-18.
3- Tawfik MS, Al-Badr N: Adverse effects of monosodium glutamate on liver and kidney functions in adult rats and potential protective effect of vitamins $\mathrm{C}$ and E. Food Nutr. Sci. J. 2012; 3: 651- 659 .

4- Erb J: A report on the toxic effects of the food additive monosodium glutamate. Joint FAO/WHO Expert Committee on food additives. J. 2006; 400-460.

5- Jinap S, Hajeb P: Glutamate. Its applications in food and contribution to health. Appetite. J. 2010; 55: 1-10.

6- Abd- Ella EM, Mohammed AM: Attenuation of Monosodium Glutamate-Induced Hepatic and Testicular Toxicity in Albino Rats by Annona Muricata Linn. (Annonaceae) Leaf Extract. Pharmacy and Biological Sciences. J. 2016; 11 (6): 61-69.

7- Kulkarni AD, Sundaresan A, Rashid MJ, Yamamoto S, Karkow F: Application of Diet-derived Taste Active Components for Clinical Nutrition: Perspectives from Ancient Ayurvedic Medical Science, Space Medicine, and Modern Clinical Nutrition. Current pharmaceutical design. J. 2014; 20: 2791-2796.

8- Seo HJ1, Ham HD, Jin HY, Lee WH, Hwang HS, Park SA, Kim YS, Choi SC, Lee S, Kim BS, Park BR, Lee MY: Chronic administration of monosodium glutamate under chronic variable stress impaired hypothalamic-pituitaryadrenal axis function in rats. Korean. Physiol. Pharmacol. J. 2010; 14: 213-221.

9- Ortiz G, Bitzer-Quintero OBeas, Za' rate C, Rodrı' guezReynoso C, Larios-Arceo F, Vela' zquez-Brizuela I, Pacheco-Moise's F, Rosales-Corral S: Monosodium glutamate-induced damage in liver and kidney: a morphological and biochemical approach. Biomed. Pharmacotherapy. J. 2006; 60:86-91.

10- Iamsaard S, Sukhorum W, Samrid R, Yimdee J, Kanla P, Chaisiwamongkol K, Hipkaeo W, Fongmoon D, Kondo H: the sensitivity of male rat reproductive organs to monosodium glutamate. Acta Medica Acad. J. 2014; 43: 3-9.

11- He K, Zhao L, Daviglus ML, Dyer AR, Van Horn L, Garside D, et al.,: Association of monosodium glutamate intake with overweight in Chinese adults: the INTERMAP. Obesity (Silver Spring). 2008; 16 (8):1875-1880.

12- Chamani G, Zarei MR, Mehrabani M, Taghiabadi Y: Evaluation of Effects of Zingiber officinale on Salivation in Rats. Acta. Medica. Iranica. J. 2011; 49: 336- 340.

13- Deavall DJ, Martin EA, Horner JM, Roberts R: Drug-Induced Oxidative Stress and Toxicity. Toxicology. J. 2012; 645460: 13. 
14- Shivasharan BD, Nagakannan P, Thippeswamy BS, Veerapur VP: Protective Effect of Calendula officinalis L. Flowers against Monosodium Glutamate Induced Oxidative Stress and Excitotoxic Brain Damage in Rats. Indian. Clin. Biochem. J. 2013; 28(3):292-298.

15- Moubarak HS, El-Bolok AH, Refaai RA: Histological and immunohistochemical evaluation of the effect of Monosodium glutamate on parotid salivary glands of adult male albino rats. Egyptian dental. J. 2015; 61, 4557:4565.

16- Leshchenko IV, Shevchuk VH, Falalieieva TM \& Beregova TV: The influence of long-term monosodium glutamate feeding on the structure of rat's pancreas. Fiziol. Zh. J. 2012; 58(2):59-65.

17- Bancroft JD \& Gamble M: Theory and practice of histological techniques. $6^{\text {th }}$ ed., 2008: 126.

18- Deraz EM,Abd-Elhamid AME, Fahmi AN: Histological and ultra structural study of the effect of potassium dichromate with evaluation of potential protective role of vitamin $C$ on submandibular salivary gland of rats. American Science. J. 2016; 12(2).

19- Garattini S: Glutamic acid, twenty years later. J. Nutr. 2000; 130: 901:-909.

20- Pavlovic V, Pavlovic D, Kocic G, Sokolovic D, Sarac M, Jovic Z: Ascorbic acid modulates monosodium glutamate induced cytotoxicity in rat thymus. Bratisl. Lek. Listy. J. 2009; 110(4): 205-209.

21- Tawfik MS, Al-Badr N. Adverse Effects of Monosodium Glutamate on Liver and Kidney Functions in Adult Rats and Potential Protective Effect of Vitamins C and E. Food and Nutrition Sciences. J. 2012; 3: 651-659.

22- Insawang T, Selmi C, Cha'on U, Pethlert S, Yongvanit P, Areejitranusorn P, et al.,: Monosodium glutamate (MSG) intake is associated with the prevalence of metabolic syndrome in a rural Thai population. Nutr Metab (Lond). J. 2012; 9(1): 50 .

23- Soliman AM: Extract of Coelatura aegyptiaca, a freshwater clam, ameliorates hepatic oxidative stress induced by monosodium glutamate in rats. African. Pharmacy and Pharmacology. J. 2011; 5(3): 398-408.

24- Diniz YS, Fernandes AA, Campos KE, Mani F, Ribas BO, Novelli EL: Toxicity of hypercaloric diet and monosodium glutamate: oxidative stress and metabolic shifting in hepatic tissue. Food Chem. Toxicol. J. 2004; 42: 319-325.

25- Minibayeva F, Kolesnikov O, Chasov A, Beckett RP, Lüthje S, Vylegzhanina N, Buck F, Böttger M: Wound- induced apoplastic peroxidase activities: their roles in the production and detoxification of reactive oxygen species. Plant Cell Environ. J. 2009; 32(5): 497-508.

26- Miletich I: Introduction to salivary glands: structure, function and embryonic development. Front Oral Biol. J. 2010; 14:1-20.

27- Jouzdani E, Yachouh J, Costes V, Faillie J, Cartier C, Poizat F: Prognostic value of a three-grade classification in primary epithelial parotid carcinoma: result of a histological review from a 20 year experience of total parotidectomy with neck dissection in a single institution. Eur. Cancer. J. 2010; 46:323-331.

28- Moreno G, Perello M, Gaillard RC, Spine E: Orexina stimulates hypothalamic-pituitary-adrenal (HPA) axis function, but not food intake in the absence of full hypothalamic NPY-ergic activity. Endocrine. J. 2005; 26: 99-106.

29- Eweka A, Om'Iniabohs F: Histological studies of the effects of monosodium glutamate on the testes of adult Wister rats. Ann. Med. Health Sci. Res. J. 2011; 1: 37-43.

30- Amano O, Mizobe K, Bando Y and Sakiyama K: Anatomy and Histology of Rodent and Human Major Salivary Glands. Acta Histochem. Cytochem. J. 2012; 45 (5): 241250 .

31- Eweka AO, Om'Iniabohs F: Histological studies of the effects of monosodium glutamate on the liver of adult wistar rats. Int. Gastroenterology. J. 2008; 6:2.

32- Eweka AO, Eweka A, Om'Iniabohs F: Histological studies of the effects of monosodium glutamate of the fallopian tubes of adult female Wistar rats. North Am. J. Med. Sci. 2010; 2:146-149.

33- Abou-Zeid AW, Hassan N, Abou El-Yazeed M: Effect of aflatoxin contaminated diet on major salivary glands and the protective role of Ozone application. Life Science J. 2014; 11(8).

34- EL-Kenawya AE, Osmanb HH, Daghestanid MH: The effect of vitamin $\mathrm{C}$ administration on monosodium glutamate induced liver injury. An experimental study. Exper. Toxic Path. J. 2013; 65:513- 521.

35- Farombi EO and Onyema OO: Monosodium glutamate-induced oxidative damage and genotoxicity in the rat: modulatory role of vitamin $\mathrm{C}$, vitamin $\mathrm{E}$ and guercetin. Human Exper \& Toxicol. J. 2006; 125: 251-259.

36- Leshchenko IV, Shevchuk VH, Falalieieva TM \& Beregova TV: The influence of long-term monosodium glutamate 
feeding on the structure of rat's pancreas. Fiziol Zh. J. 2012; 58(2):59-65.

37- Bhattacharya T, Bhakta A, Ghosh SK: Long term effect of monosodium glutamate in liver of albino mice after neonatal exposure. Nepal Med. College J. 2011; 13(1):11-16.

38- Koda M, Takemura G, Okada H, Kanoh M, Maruyama R, Esaki M, Li Y, Miyata S, Kanamori H, Li L, et al.,: Nuclear hypertrophy reflects increased biosynthetic activities in myocytes of human hypertrophic hearts. Circ. J. 2006; 70(6):710-718.

39- AL-Mosaibih MA: Effects of monosodium glutamate and acrylamide on the liver tissue of adult Wistar rats. Life Sci. J. 2013; 10:35-32.

40- Khalaf HA, Arafat EA: Effect of different doses of monosodium glutamate on the thyroid follicular cells of adult male albino rats: a histological study. Int. J. Clin. Exp. Pathol. 2015; 8(12):15498-15510.

41- Alalwani AD: monosodium glutamate induced testicular lesions in rats (histological study). Middle East. Fertility. Society. J. 2013; 19(4): 274- 280.

42- Kumbhare V, Gajbe U, Singh B.R, Reddy A.K, Shukla S. Histological \& histochemical changes in liver of adult rats treated with monosodium glutamate: a light microscopic study. WJPPS. J. 2015; 4(04):898-911.

43- Dixit SG, Rani P, Anand A, Khatri K, Chauhan R, Bharihoke V: Study the effect of monosodium glutamate on histomorphometry of cortex of kidney in adult albino rats. Ren. Fail. J. 2014; 36(2): 266-270.

44- Rani P, Khatri K \& Chauhan R. Monosodium glutamate induced histomorphometric changes in thyroid gland of adult wistar rat. Med. Allied Sci. J. 2013; 3 (2):67-71.

45- Kumbhare V, Gajbe U, Singh B.R, Reddy A.K, Shukla S: Histological \& histochemical changes in liver of adult rats treated with monosodium glutamate: a light microscopic study. WJPPS. J. 2015; 4(04):898-911.

46- Alalwani AD: Monosodium glutamate induced testicular lesions in rats (histological study). Middle East Fertility Society J. 2013; 9(6):274-280.

47- Oladipo IC, Adebayo EA, Kuye OM: Effects of monosodium glutamate in ovaries of female sprague-dawley rats. Int. Curr. Microbiol. App. Sci. J. 2015; 4(5):737-745.

48- Eweka AO, Om'lniabohs FAE: Histochemical studies of the effects of Monosodium glutamate on the liver of wistar rats. Annals Med. Health Sci. Res. J. 2011; 1: 21-29.

49- Lee KT, Sheen PC: Study of lysosomal changes in rat pancreas after ingesting monosodium L-glutamate. Pancreas. J. 1994; 9: 304-308.

50- Afeefy AA, Mahmoud MS, Arafa MA: Effect of Honey on Monosodium Glutamate Induced Nephrotoxicity (Histological and Electron Microscopic Studies). American Science. J. 2012; 8: 146-156.

51- Thomas S: Text atlas of Histology W.B. Saundrs company, Philadelphia. 1988.

52- Adejoke YO, Olakunle JO, Tolulope JM, Onigbinde O, Akanji 1, Oyeleke A1: A Histological Study of the Hepatic and Renal Effects of Subchronic Low Dose Oral Monosodium Glutamate in Swiss Albino Mice. British. Medicine \& Medical Research. J. 2013; 3(2): 294-306.

53- Moubarak HS, El- Bolok AH, Refeaai RA: Histological and immunohistochemical evaluation of the effect of monosodium glutamate on parotid salivary gland of adult male albino rats. Egyptian dental. J. 2015; 61: 4557:4565.

54- Shredah MT, Nagy DA: effect of monosodium glutamate on sublingual salivary glands of rats (histological and histochemical study. Egyptian dental. J. 2017; 63: 753-760. 